\title{
VEBLEN AND THE THEORY OF THE BACKPACKER LEISURE CLASS: STATUS SEEKING AND EMULATION IN THE AUSTRALIAN CONTEMPORARY TOURIST ECONOMY
}

\author{
WENDY HILLMAN \\ Institute for Health and Social Science Research, Faculty of Science, Engineering and Health, \\ CQUniversity, North Rockhampton, Queensland, Australia
}

In 1899 Thorstein Veblen wrote a seminal monograph on the subject of consumption and leisure. His work, The Theory of the Leisure Class, is one of the most enduring examples of status-seeking individuals' conspicuous consumption and conspicuous leisure practices, particularly when applied to the tourist industry, and furthermore, is still relevant in today's economic climate. This article develops an independent theory of backpackers and how they can be perceived as undertaking conspicuous consumption and conspicuous leisure practices. This is done using Veblen's work as a foundation. Qualitative methods using in-depth interviews and participant observation techniques are employed to obtain data from 41 participants. The findings serve to highlight the fact that Veblen's thesis is as relevant today as it was when it was written in 1899.

Key words: Veblen; The theory of the leisure class; Backpackers; Conspicuous consumption; Conspicuous leisure; Australia

\section{Introduction}

For hundreds of years many people have sought to visit destinations as independent travelers. This self-sufficient form of travel can indeed be linked back to the time of the Pharaohs (Dewar, 2000, p. 17). In more recent centuries, traveling as a form of religious pilgrimage was perceived as a rite of passage by those who completed such a task (Gluckman, 1962, p. 2; see also MacCannell, 1976; Noy, 2008). In contemporary society, the independent traveler has become something of a symbol
(D'Andrea, 2006, p. 106). Many of these, usually young people aged in their early twenties, seek to obtain the "best value for money" trip. They believe that the lower the price the better the experience (Hillman, 1999; Noy, 2008).

Bearing in mind this type of international, longterm budget traveling (Jarvis, 1994), there are a number of issues that can be investigated using Veblen's (1899) theory of the leisure class as a foundation. Many backpackers are not seen as high status travelers, even though their money and their contribution to work adds much to the econo- 
mies where they undertake their journeys (see Munt, 1994). Furthermore, backpackers are also frequently portrayed as time rich and resource poor (Munt, 1994, p. 111). Moreover, Veblen is not the only theorist to write about consumption and its connections to travel (see also Cohen, 1979a, 1979b, 1989; MacCannell, 1973, 1976; Munt, 1994; Urry, 1990). In this case, this article is an examination of the relevance of Veblen to travelers consuming conspicuously in the $21 \mathrm{st}$ century.

Veblen wrote his seminal work at the end of the 19 th century. His notions of conspicuous consumption and conspicuous leisure are rooted in his wider knowledge of the abyss between the upper classes and their servants. The acquirement of property, goods, workers, and wealth, generally, form the basis of his observations and writings about the economic surplus value of rich families and institutions. Veblen generally criticized Marx's third volume of Capital, as an account lacking in an explanation of the ambiguities of surplus value theory. So, by the time Veblen began to write his manuscript on the leisure class, he was focusing on theories connected to both socialism and Marxw ism, and other ideas associated with why poorer people wanted to emulate the rich and their social status. Marx saw the exploitation of the working class, whereas Veblen realized the lower classes were becoming mesmerized by the consumption of status in society (Brown, 1998b). In other words, they were "trying conspicuously to be something they were not" (Brown 1998a, p. xvi).

As a group of contemporary consumers, this article suggests that backpackers are a distinct leisure class of their own, distanced from, and by, the mainstream tourism product (Barrett, 1989; Lash, 1991; Urry, 1990). This article also examines how backpackers use both conspicuous consumption and conspicuous leisure to position themselves in the tourist market, and how this differentiates them from the mainstream tourist industry (Cohen, 1979b, 1979c, 1989; Featherstone, 1991; Lash, 1991; Munt, 1994; Urry, 1990).

The findings of the research are examined through the contemporary backpacker consumption and leisure experience, and related to Veblen's (1899) seminal monograph, The Theory of the Leisure Class. First, the theoretical back- ground of Veblen's work and the notion that tourism is part of the progression of commodification intrinsic to contemporary capitalism is examined. Second, the methodological approach to the research is made clear. Third, the findings of the research are described, using categories of conspicuous consumption, conspicuous leisure, emulation, and status seeking or honorific behavior. Last, a conclusion and significance of the findings are stated.

\section{Theorizing Veblen and The Theory of the Leisure Class}

Veblen (1899) suggests that the existence of a "leisure class" can be related back to slowly evolving "primitive" cultures. Even though there was little difference between individuals in early communal societies, once the concepts of job and employment became more clearly outlined, the subsequent division of labor allowed differences to be drawn between the working and leisure classes within those societies. A person's capacity to express membership of the leisure class brought with it social ranking and personal esteem within the society. This membership was established through ownership and possession (Mason, 1998. pp. 52-53).

While it is established that Veblen wrote The Theory of the Leisure Class as a contribution to economic theory (Veblen, 1899, p. xiii), the work itself can also be interpreted as a treatise in social inquiry (cf. McFarland, 1991, p. 89). It was an indication of Veblen's intellect that he established that consumption is a part of the system of emblematic communication in use in human society. But while there was virtually no scholarly work that Veblen could use as a reference to supply him with a sufficient sociological understanding of the symbolic purpose of material items and services, he made suppositions about their significance and social meaning from reading historical works of contemporary efforts by cultural anthropologists concerning life in "primitive" societies. In summary, Veblen used a means of a "speculative anthropology" (Haight, 1997, p. 30). Veblen "established" those assumptions through instances evolving from of his own perceptions and analysis of the consumption practices he observed in the United 
States of his generation (Ramstad, 1998, p. 4). Rojek (1995) views Veblen's argument as having a strong social aspect and suggests that "Veblen [1899] sees leisure in consumer culture as intrinsically alienating because it does not spring from real needs in the individual but from the individual's perception of what society requires of him or her" (Rojek, 1995, p. 74).

Veblen's analysis in its entirety highlights a culture inspired by consumption. Given that the industrial economy that Veblen was writing about provided the basic biological preservation requirements of the population and produced an unparalleled amount of surplus, the bulk of the consumable items met the requirements of continuing the invidious forms of honor, that is, the dubious positions of respect, essential to the status, or class, system. The status system was based on a hierarchical ranking system, with those who owned more wealth, and therefore more time to pursue leisure at the top. But the status system required that the amount and the quantity of conspicuous consumption and leisure had to continually increase (Waller \& Robertson, 1998, p. 32). Conspicuous consumption can be defined as obvious or noticeable, that is, intended levels of the use of goods and other people's labor. Thus the social order required ever mounting levels of superfluous consumption purely to sustain itself (Waller \& Robertson, 1998, p. 32). Superfluous consumption can be defined as the excessive or abundant use of goods, services, and products not necessary to basic survival or continued existence. Tourism falls into this category. Urry (1990) also applies this argument to the case of tourism and states that

If people do not travel, they lose status: travel is the marker of status. It is a crucial element of modern life to feel that travel and holidays are necessary. 'I need a holiday' is the surest reflection of a modern discourse based on the idea that people's physical and mental health will be restored if only they can 'get away' from time to time. (Urry, 1990, p. 5)

MacCannell (1976) draws heavily on Veblen's (1899) The Theory of the Leisure Class. Yet, despite this indebtedness, there is almost no similarity between their findings. MacCannell uses Veblen's notion that leisure mirrors social structure.
However, MacCannell bases his analysis of leisure on the selection of elements from tourism, whereas Veblen grounds his analysis in the class structure and highlights the uneven distribution of work in society and the status mechanisms of leisure; for example, the way leisure is consumed conspicuously as a representation of superior social positioning (MacCannell, 1976).

The Theory of the Leisure Class supplies us with an economic theory that cannot be separated from an understanding of cultural structures, historical influences, and social values. Veblen presents a significantly inclusive theory for conceptualizing economic organization and its effect on the construction of the social order and the individual. He does not just simply present a theory of consumption, or a narrow parody of etiquette (Waller \& Robertson, 1998, p. 30).

Overall, the central theme of this article is that tourism is part of the progression of commodification intrinsic to contemporary capitalism. Tourism is therefore best theorized as a global process of commodification and consumption that entails the movement of capital, cultures, images, and people (Appadurai, 1990; Clifford, 1997; Frow, 1997; Lanfant, Allcock, \& Bruner, 1995; Meethan, 2001). This author believes that Veblen would agree.

\section{Research in the Backpacker Tourist Market}

A complicating characteristic of contemporary consumption is the presence of youth subcultures and their impression on the "culture of youth." Veblen never really theorized youth as a separate section of the consumer masses. In fact, it was not until the post-Second World War era that "youth" became a noticeably identified social group that was associated with standards of taste distinct from the rest of society (Lury, 1996, p. 194, as cited in Ramstad, 1998, pp. 15-16). There are reported to be three principal features of youth cultures. They are "cultures of leisure rather than work; within them, social relationships are organised around the peer group rather than on an individual basis"; and their constituents exude a prevailing anxiety about style (Lury, 1996, p. 196; as cited in Ramstad, 1998, pp. 15-16).

Many publications on, or about, backpacker and tourist adventures tend to romanticize tourism 
as an increasing part of workers' leisure time and space (Buchanan \& Rossetto, 1997; Haigh, 1995; Hillman, 1999; Jarvis, 1994; Loker, 1993; LokerMurphy \& Pearce, 1995). That is, the nomadic life of traveling freely, visiting places and sites as one chooses, has become part of this subculture of tourism generally (Noy, 2008; Uriely, Yonay, \& Simchai, 2002). Also, despite popular opinion, backpackers tend to be middle or upper class, or semiprofessionals and not drawn from the lower socioeconomic end of the scale (Hillman, 1999; Jarvis, 1994; Loker, 1993; Loker-Murphy \& Pearce, 1995; Munt, 1994). Therefore, many of the backpackers in this study are able to practice conspicuous consumption, conspicuous leisure, emulation, and status-seeking or "honorific" behavior. That is, they display stereotypical behavior, even though they want to be perceived as "the" group of independent travelers. This relaxed and nomadic lifestyle roaming the globe is often due to the wealth of the backpacker's parents and families, not their own fiscal affluence (see Buchanan \& Rossetto, 1997; Cohen, 1973; Haigh, 1995; Hillman, 1999; Jarvis, 1994; Loker, 1993; Loker-Murphy \& Pearce, 1995; Munt, 1994).

Although there are a number of studies of backpackers themselves, they have not been investigated from the perspective of the use of conspicuous consumption and conspicuous leisure (Lee, 1999; Walmsley, 2003). Backpackers' penchant for similar modes of dress, tours undertaken, status-seeking behavior, and emulation of one another have also been lacking in much of the tourism and other literature (Munt, 1994). Although there are a large number of studies, in the area of Psychology (see for example, Pearce, 1990; Ross, 1992, 1993), regarding backpackers, there has not as yet been any extensive sociological research specifically relating to the experiences of this nonmainstream tourist group (see D'Andrea, 2006, p. 113; Noy, 2004; Noy, 2008).

For this research project, a sample of one combined backpackers and guesthouse accommodation place situated in the provincial town where the author lived at the time was selected. This establishment reflected a representative sample of all local backpacker accommodation places because it catered for long-term budget travelers by providing facilities such as a large kitchen and dining area and various levels of sleeping arrangements, together with recreational activities, all at minimal and affordable prices. It was a basic accommodation house clearly catering to a low budget, backpacking lifestyle, and typical of other backpacker hostels where the author had sojourned while trav eling. The author was granted access to the site and the backpackers themselves through the owner.

A total of 35 , in-depth, open-ended interviews were conducted over a 6-month period, sometimes with one or more participants. The author interviewed 41 individuals in total. A number of openended questions were asked. The questions covered issues such as country of origin; length of time traveling; countries visited; length of stay in Australia; modes of travel; interaction and contact with other travelers and locals; and other questions pertaining to backpacker culture and travel. All interviews were recorded and transcribed for efficacy of later recollection and for coding purposes. The interviews were then coded using thematic analysis (Denzin \& Lincoln, 1994; Kellehear, 1993; Miles \& Huberman, 1994). More women than men were interviewed while undertaking the data collection. This may have been due to any number of factors. The author observed, while undertaking this study, that there were more women traveling, either alone or in groups, than males. Riley (1988) makes a similar point and suggests that, "These people are at one of life's junctures. For example, they have just completed a college degree or are between jobs... . A surprisingly large number of budget travelers ... are women" (pp. 317-318; see also Elsrud, 2001; Hall \& Kinnaird, 1994). Every interviewee in the study was assigned a pseudonym, in keeping with university policies of ethics and participant anonymity. Initially, university research ethics approval was sought and obtained through the author's university Research Office. Table 1 sets out some of the main demographic findings for the participants in the research. In no specific order, categories such as age, country of origin, length of stay, mode of transport around Australia, gender, education level, and country of origin occupation are included to provide a more comprehensive view of the research cohort. The blank cells indicate that no data was collected or available for that category regarding that particular participant. 
Table 1

Backpacker Demographics

\begin{tabular}{|c|c|c|c|c|c|c|c|}
\hline Name & Age & $\begin{array}{l}\text { Place of } \\
\text { Origin }\end{array}$ & $\begin{array}{c}\text { Length of } \\
\text { Stay (Months) }\end{array}$ & $\begin{array}{l}\text { Mode of } \\
\text { Transport }\end{array}$ & Gender & $\begin{array}{c}\text { Education } \\
\text { Level }\end{array}$ & Occupation \\
\hline Boronia & 25 & Spain & 1 & Bus & Female & & \\
\hline Evelyn & 24 & Denmark & 12 & Bus & Female & & Typographer \\
\hline Saiko & 21 & Japan & 6 & Bus & Female & Secondary & Waitress \\
\hline Yoko & 20 & Japan & 6 & Bus & Femate & Secondary & \\
\hline Cathy & 26 & Scotland & 12 & Bus & Female & Secondary & Pastry cook \\
\hline Veronica & 25 & Denmark & 1 & Bus & Female & & Clerk \\
\hline Will & 26 & Denmark & 1 & Bus & Male & & Clerk \\
\hline Hans & 22 & Denmark & indefinite & Car & Male & Secondary & Kindergarten assistant \\
\hline Cynthia & 22 & Denmark & indefinite & Car & Female & & \\
\hline Anne & 23 & Ireland & 12 & Bus/camper & Female & & Nurse \\
\hline Greta & 22 & Holland & indefinite & Bus/car & Female & Tertiary & Historian \\
\hline Sally & 24 & Holland & 12 & Bus & Female & Tertiary & \\
\hline Juliá & 28 & Ireland & 12 & Car & Female & Tertiary & Teacher \\
\hline Jean & 23 & England & 12 & Bus/train & Female & & Nurse \\
\hline Harry & 25 & Sweden & 2 & Bus & Male & Secondary & Unemployed \\
\hline Serena & 26 & Sweden & 2 & Bus & Female & Tertiary & Nurse \\
\hline Annette & 20 & Sweden & indefinite & Bus & Female & Secondary & Supermarket worker \\
\hline Lisa & 20 & Sweden & indefinite & Bus & Female & Secondary & Supermarket worker \\
\hline Marianne & 21 & Denmark & 8 & Bus & Female & Tertiary & Day care worker \\
\hline Anita & 28 & Mexico & 3 & Bus & Female & Tertiary & Industrial designer \\
\hline Carolyn & 27 & Wales & 12 & Plane/bus & Female & Tertiary & Pharmacist \\
\hline Kate & 21 & England & 9 & Bus & Female & & \\
\hline Megan & 35 & Ireland & 4 & Bus/plane & Female & & Secretary \\
\hline Lee-anne & 26 & Canada & 12 & Bus & Female & Tertiary & Environmental consultant \\
\hline Caterina & 25 & Brazi] & 5 & Bus/train & Female & Tertiary & Journalist \\
\hline Germaine & 27 & Ireland & 9 & Bus/plane & Female & Tertiary & Accountant \\
\hline Miranda & 25 & Ireland & 6 & Bus/plane & Female & Secondary & Secretary \\
\hline Susan & 21 & Sweden & 10 & Bus & Female & Secondary & \\
\hline Mandy & 26 & Ireland & 12 & Bus & Female & Tertiary & Accountant \\
\hline Melissa & 20 & Sweden & 10 & Bus & Female & Secondary & \\
\hline Meike & 21 & Switzerland & 5 & Car & Female & Secondary & Computer work \\
\hline Beris & 28 & Tunisia & 4 & Bus & Female & Tertiary & Engineer \\
\hline Charlotte & 24 & England & 12 & Car/bus & Female & Secondary & Secretary \\
\hline Robyn & 32 & Germany & 6 & Bus & Female & Tertiary & Nurse \\
\hline Jocelyn & 19 & England & 1 & Bus & Female & Secondary & Music video production \\
\hline Adele & 19 & England & 3 & Bus & Female & Secondary & Secretary \\
\hline Jacqui & 26 & England & 12 & Car & Female & Tertiary & Computer analyst \\
\hline Lucy & 26 & England & 12 & Car & Female & & Nurse \\
\hline Clare & 24 & lreland & 12 & Bus/plane & Female & Secondary & Clerk \\
\hline Regina & 35 & England & 6 & Bus & Female & Secondary & Silversmith \\
\hline Tom & 27 & Australia & & & Male & Tertiary & Hospitality worker \\
\hline
\end{tabular}

Table 1 provides a significant explication of the background of the backpacker participants traveling around Australia in this study. It is apparent that many of the backpackers in this investigation have attained, or will attain, at least a tertiary educational level, and that most have been in paid employment. Many of the backpackers are taking at least 6 to 12 months away from work or study to travel (see also Noy, 2008). This is commonly referred to as the "gap" year (O'Reilly, 2006; Simpson, 2005). Many of these independent trav- elers were also from Europe. A minority were from other eclectic global points of departure. Most were traveling "around Australia" by some form of road transport (see Munt, 1994, p. 114). These individuals were conspicuously consuming Australia and all it had to offer them. In Munt's (1994) words, they had become "ego-tourists" (1994, pp. 108, 112, 116).

This study of backpackers, within the context of the Australian tourist industry, is receptive to identifying the salient issues of conspicuous con- 
sumption, conspicuous leisure, emulation, and stam tus-seeking or "honorific" behavior, relevant to the contemporary tourist economy through the lens of Veblen's The Theory of the Leisure Class. An examination of Veblen's (1899) work allows us to gain an understanding of the backpackers and their ways. The notion of cost and of payment, in advance, for services as yet to be delivered or undertaken, is only one of the notable fiscal assumptions within the concept of economic and cultural exchange in return for the price of a holiday. What this means is that these enduring relations of services and payment for the services are developed by one section of the backpacker group in order to show their dominance and elevated status over other backpackers. These ideas lie at the very foundation of Veblen's argument and are discussed in the next section.

\section{Findings}

This section of the article sets out the links between Veblen's classic monograph and the backpacker participants in this study. Four sections are used to relate Veblen's ideas about economic values to a traveling, backpacker lifestyle. These sections are conspicuous consumption, conspicuous leisure, emulation, and status-seeking behavior. Throughout this section backpackers' experiences, using the transcribed interviews and coded data, illustrate how each of Veblen's notions of economic life fit into the contemporary existence of the backpacker subculture.

\section{Conspicuous Consumption}

From the research undertaken, and other literature consulted, it became apparent that the backpackers in this study are traveling the world in search of the "ultimate deal." In other words, they are consuming sites throughout the globe, while at the same time, seeking the ultimate experience for the lowest price possible. Backpackers are a select part of the leisure class (see D'Andrea, 2006, p. 110). And, "in the nature of things, luxuries and the comforts of life belong to the leisure class" (Veblen, 1934, p. 70). Moreover, "the consumption of luxuries, in the true sense, is a consumption directed to the comfort of the consumer himself [sic]" (Veblen, 1934, p. 72).
As cost of travel can be prohibitive for some, fiscal considerations are an important aspect of any traveler's journey. However, backpackers frequently begin their holidays and worry about how to pay for it later. One of the backpackers in the study commented on the price of travel and accommodation while traveling in Australia. She had purchased a return ticket, from her country of origin, but had not really considered the price of traveling around Australia at all.

\begin{abstract}
You've got to budget your money, and that's really hard. When you go on a package holiday, you know, you pay the bulk and then it's little things that you pay for, you know, you stick on your credit card. Yeah. It's just like you haven't paid for anything. You've just literally bought your flight. You've got to sort out the travel, up and down [the east coast]. You've got to sort out the hotel accommodation. But we thought we could get a ticket from Airlie Beach to Cairns, and stop off at places. But, it turns out we can't. And we've sort of . . . in my head, I've put that money aside for that ticket. Now we haven't bought that ticket. We've bought it from here [Airlie Beach] to Townsville, from Townsville to ... And now it's like l've got to put more money aside. It's like you planned it all [but you haven't, really]. (Jocelyn, 19, England)
\end{abstract}

According to Mason (1981), assertive endorsement of credit business has also been allocated a position (Mason, 1981, p. 118), in the life of conspicuous consumption (Brown, 1998b, p. 13). Jocelyn's friend also found it difficult to accept that it was very expensive initially, and then budgeting became the norm for the duration of the travel experience.

What I found in the first couple of days was buy-
ing the VIP ticket, buying your coach ticket. You
find that you spend a lot in the beginning then
you have to budget yourself. We've budgeted
ourselves to about twenty-five, to spending money,
to about twenty-five/thirty dollars per day. Like
eating, drinking and umm ... just that kind of
thing. (Adele, 19, England)

Munt (1994) refers to this as, "a class fraction that attempts to compensate for insufficient economic capital, with an obsessional quest for the authentication of experience" (p. 108; see also Cohen, 1979b, 1979c; Errington \& Gewertz, 1989; 
Noy, 2004, 2008). The constant search for the best value for their tourist dollar and the need to see as many sites as possible, for the cheapest price possible, leaves the backpackers with very little choice. In fact, they are treated as if they are ordinary "mass" tourists by many alleged backpacker service providers (see Lash, 1991, p. 49; Munt, 1994 , p. 109; Noy, 2008). This is not in keeping with Veblen's conspicuous consumption status, but indicates backpackers still like to feel that they have conspicuously consumed even though the consumption may not be of a high level. Sharpley (1994) further underlines Adele's point by maintaining that

tour operators are only able to sell cheap, mass produced package holidays to a large number of tourists if the tourists themselves are willing to accept the lack of choice, the impersonal service, basic standards of food and accommodation, and cramped transport. (Indeed, a common criticism of package holiday tourism is that the tourist is frequently treated more like a unit of production than a consumer!) Once an element of choice or a demand for non-standard products enters the system then the basis of mass production is undermined; the principles of Fordism no longer apply. (pp. 243-244)

This can be further substantiated by arguing that the most important attribute of backpacking journeys is an almost overwhelming obsession with frugalness with regards to the prices of just about everything, including accommodation, food, and methods of traveling around the country (Riley, 1988, p. 320). The point related to Veblen here is that backpackers have a unique perspective and attitude towards spending money and trying to eat well. They are seeking status as a bonafide independent traveler. In other words, how they "consume conspicuously" is forever being scrutinized by the other backpackers they travel with and meet along the way, and also by tourist industry workers connected with their travel experience (see Campbell, 1995, p. 41; Noy, 2004, 2008). Therefore, according to the backpackers in this study, living and eating as cheaply as possible leaves more money to be spent on desired experiences and unusual tourist activities (i.e., conspicuous consumption); those tourist pursuits that perhaps other travelers may not experience (see Vogt,
1976). As Waller and Robertson (1998) further suggest, "the demand that the individual lives vicariously, constructing his or her identity out of the effort to conform to the standards of consumption set by his or her status group underlines Veblen's theory of consumption" (p. 28).

The concept of backpackers not being as poor or as strapped for cash as is made out was highlighted by one female. She understood this to be a way of travelers from well-to do families expressing their wish for independence from familial ties, even though they still had the back up of their parents' money only a telephone call, email, or text message away.

You get to see more, definitely, but it's just an economized way of seeing it. There's nothing wrong with that. There's [sic] probably a lot of people, in that hostel, that come from very rich families and have wealthy parents. It's sort of their way of saying, "We don't need our parents. We can do it on our own." Which it is completely. (Jocelyn, 19, England)

The conspicuous consumption of travel destinations and backpacking experiences are purchased and commodified through the use of perceived "hardship" and privation. Being perceived as poor and of a lower income group is, within backpacker culture, seen as being able to afford to go without necessities in order to afford the ultimate tour, experience, or encounter, the conspicuous consumption part of the travel. In fact, approximately $50 \%$ of backpackers in this research reported having the fiscal advantage of rich parents at home, who provide necessary amounts of cash, as needed by their nomadic children, who can then continue to travel the globe, conspicuously consuming sites and experiences until they, or their parents, tire of the activities occurring, and return home to pursue other forms of conspicuous consumption, and perhaps leisure (see Bourdieu, 1984; Munt, 1994, pp. 106-107). Therefore, the backpackers in this research can achieve their desired level of status via their families who have achieved, most probably in other ways, the status the backpackers seek.

\section{Conspicuous Leisure}

Backpackers enjoy a lifestyle all their own. They are seemingly free to travel at will, to see 
and to do; what they desire when they wish to, and their time is their own. They can take all of their itinerary time residing in one spot or they can travel across the country in a few days. It is apparent that backpacking promotes the notion of freedom, as the backpackers do not have to adhere to timetables and itineraries (see D'Andrea, 2006, p. 108; Noy, 2004, 2008). If they wish to stay and experience one particular part of the country for a lengthy period, they are able to do so. Thus, conspicuous forms of leisure are a part of their daily existence.

Leisure, holidaying, and the idea of fun are the all important ingredients for the successful backpacking journey. The backpackers in this study reported on traveling in small groups, or sometimes singly, and for short periods. As Riley (1988) notes "Of those travelling alone (actually most long-term budget travellers do so; when they are with others it tends to be a temporary arrangement), many relished the opportunity to feel free of social pressures and constraints" (p. 318).

One common explanation of why backpackers feel the need to travel and been seen to be "consuming" leisure, is that they do so to gain independence. Consider the examples listed below from three backpackers from very diverse countries.

I know a lot of people do travel because they want to escape home and they like, not run away, but just be away from their folks and people who are around all the time. Most teenagers do that. (Anita, 28, Mexico)

You get away from the mother's wing, you know. To do what you want type of thing. Yeah, I guess it could be that. Escape ... (Lee-anne, 26, Canada)

And I think like all the people we've met, the majority of people that we've met are all escaping from something. I mean, a lot of people are taking a year out of university. (Jocelyn, 19, England)

This can be directly related to both Bourdieu's The Field of Cultural Production (1993) and Distinction (1984), where he concludes that "the representation which individuals and groups inevitably project through their practices and properties is an integral part of social reality. A class (or in this case, sub-culture) is defined as much by its being-perceived and by its being, by its consumption-which need not be conspicuous to be symbolic-as much as by its position in the relations of production" (Bourdieu, 1993, as cited in Munt, 1994, pp. 106-107; see also Johnson 1993, p. 4; Anheier, Gerhards, \& Romo, 1995). The escapades of this group of participants fit well with Veblen's theory of conspicuous leisure because they freely consume leisure wherever they may be on the planet. Nash (1989) also has an explanation for this idea of conspicuous leisure and believes that

Tourism arises when people use the available means of travel for leisure-time pursuits. At the point in the industrial cycle where significant tourism appears, people are beginning to live in a society where productivity is great enough, the horizons broad enough, and the social mobility significant enough to nourish the touristic impulse. (p. 40)

However, some backpackers do not see this type of pilgrimage as the consumption of leisure for its own sake. Some believe it is a search for something else, perhaps a search for self-identity, or self-perception, to be able to place yourself within the context of society.

\begin{abstract}
Maybe not escaping, but trying to find something as well. I think escaping, you know, depends on what people are escaping from. But, I don't know, it's a kind of escape, yeah. (Caterina, 25, Brazil)
\end{abstract}

I think people who don't do it think it's escapist. A couple [of people] have said it to me. (Germaine, 27, Ireland)

Therefore, the conspicuous leisure consumed in this case is evident in the backpacker subgroup themselves, but not necessarily in the mainstream tourist market. So it follows that much of the status seeking and emulation is within and between the backpacker group itself, rather than from a comparison with other external tourist groups.

Backpackers in the participant group saw themselves as nonconformist traveler types. They did not correspond to notions of tourism largely held by society and the tourist industry. They believe 
that they are travelers as opposed to tourists because they travel for at least 6 months and, at times, for much longer periods (see, for example, Munt, 1994; Vogt, 1976). For some of the backpackers their travel itineraries have set time frames. For some, these vary from a few weeks up to 12 months (Buchanan \& Rossetto, 1997, p. iii). For a few others traveling has become their way of life and the travel can last for a number of years (D'Andrea, 2006, p. 97). One of the backpackers interviewed had this to say about the polarity between traveling and touring

People who travel for six weeks or less are not travellers they"re tourists. (Tom, 27, Australia)

The distinction between traveler and tourist is developed by Munt (1994) and Riley (1988, p. 317) and is further expanded by Jarvis (1994), who found in his study of backpackers as fully independent tourists that

\begin{abstract}
Backpacking tourism does not conform to both the public's and the industry's standard image of tourism. For a start how could someone consider travelling for one year or more? It is this basic lack of understanding of the motivations and characteristics of the backpacker market that is preventing the Australian tourism industry (and other countries) from taking full advantage of the opportunity that presents itself in the form of this market. (emphasis in original)
\end{abstract}

The point of the argument here is that Munt, Riley, and Jarvis believe that backpackers form a distinct leisure class of their own. For Veblen's theory to hold true, there must be a distinct "leisure class" making society aware of its pattern of fiscal soundness. The significance of the "new" viewpoint on consumption is its highlighting of the gradually more focal position of the "art-culture system" (Lury, 1996, p. 53). Some of these systems include: "visual art, literature, music, radio, films, television." These systems are fundamental in shaping the imagery of the egocentric expression [that is, Munt's (1994) ego-tourist, i.e. backpackers] for the contemporary analysis of commodity usage (Ramstad, 1998, p. 18).

At least nine of the participants in this study reported traveling the globe for extended periods of time. The author interviewed one backpacker that has taken the lifestyle on board and at the moment, traveling defines her life. She has been traveling the world for a long time. "Yeah, two and a half... almost three years" (Anita, 28, Mexico). This notion of conspicuous leisure is also supported by Riley (1988), who suggests that "It was not uncommon to meet people who had been away from home for three or four years. The longest time for any of the subjects of in-depth interviews was seven years" (p. 320).

This notion of traveling the world in a longterm, nomadic fashion can be seen as a temporary rejection of the work ethic through trying to "find" oneself and partaking of activities and experiences that others are not doing (see Veblen 1899, 1934). It is also can be perceived as a very underrated use of conspicuous leisure on a global scale. Traveling the world, and Australia, at your leisure is seen as customary for the rich and idle classes (see D'Andrea, 2006, p. 98). Backpackers, however, have challenged this myth by imitating the' rich and idle through their travel pursuits and leisure parallels. This line of thought fits well with Veblen's The Theory of the Leisure Class, and supplies a logical examination of the required demand for establishing one's identity as an image; for existing vicariously through the representations of consumption and surplus that define one in terms of status (Waller \& Robertson, 1998, p. 43).

As already argued, most backpackers do not conform to the norm with regard to touristic "types." They tend to travel much further and for much longer than "ordinary" tourists (Buchanan \& Rossetto, 1997; Jarvis, 1994; Munt, 1994; Murphy, 1998; Riley, 1988; Vogt, 1976). However, these are not hard and fast categories, but it is apparent that backpackers do use the dichotomy (and contradiction) between traveling and touring. One of the research participants explains her conspicuous leisure pursuits when "holidaying" at a working cattle station.

Went to Byron Bay, stayed for a couple of days. Noosa, Hervey Bay, Airlie Beach, went to Dingo Cattle Station, awesome experience. Went for horse rides, motorbike rides also. Went to an $\mathrm{Ab}$ original reserve and we went to the woods, chopped a tree and made a didgeridoo, and $I$ have it upstairs, and I painted it. You have a very good experience there. You can do sapphire mining 
too. Just do several activities there, (Anita, 28, Mexico)

Indeed, as argued by Lury (1996), a definite move from the consumption of commodities to the consumption of "empirical" goods and services [such as fully escorted package tours or trips to iconic sites such as Uluru (Ayers Rock)] has happened. Further, Noy (2008) also contends that "participation in several activities is a travelling 'must,' and inevitability" (p. 6).

Conspicuous leisure is a form of travel pursued by backpackers in their search for the "ultimate" experience for the cheapest price. Cramming as many experiences as possible into one destination can be exhilarating for the backpacker, because they have achieved the ultimate in experience commodification. In many cases, they have paid one price for numerous tourist activities. Therefore, they perceive that they have received many experiences for the price of one. They bought for one fee and therefore paid one price for various touristic consumption pursuits. As noted above, at least five activities can be had for the all-encompassing price of one destination fee, such as: stay ing at a cattle station; horse riding; motor bike riding; didgeridoo making; and sapphire mining. It could be argued that this is the highest pursuit of conspicuous leisure available worldwide. As suggested by Coleman (1983), "lifestyle should not replace social class, but exist in combination with it" (p. 269; see also Ramstad, 1998, p. 19). Pointedly, this is at odds with the argument that backpackers are not on a package holiday, but are instead buying their experience on a piecemeal basis. Again, this indicates the contradiction that backpackers are free to opt in or out of the travel industry when, and how, they choose.

\section{Emulation}

"In these times then consumption is driven by emulating and vicarious living as suggested by Veblen" (Waller \& Robertson, 1998, p. 46). Thus, particularly within backpacker circles, identity is an integral part of being able to recognize an individual or a group through particular characteristics. In order to determine a person as belonging to a certain classification it is necessary to explore some of the characteristics belonging to the group and its individuals. These characteristics can be derived from the manner in which the group or the individuals behave and from their preferences and goals (Campbell, 1995, p. 39). Backpackers have certain characteristics as a subgroup or subculture within tourism (Noy, 2008; Uriely, Yonay, \& Simchai, 2002; Vogt, 1976). Some of these emulative practices include the sight sacralization (see MacCannell, 1976) of many (in this case) Australian tourist representations.

All of the backpackers interviewed had been to see or were going to see the major tourist attractions and icons of Australian culture. For example, all the travelers wanted to see the Sydney Opera House, the Sydney Harbour Bridge, Uluru (Ayers Rock), Fraser Island, the Great Ocean Road, the Great Barrier Reef, and the Daintree Rainforest. Some of them explain their similar and emulative sightseeing practices.

$I$ drove around Victoria, with friends, up to the Grampians [Mountain range]. It was beautiful. I just loved it. And the Great Ocean Road. Fantastic. I saw a seal colony and the Twelve Apostles. (Regina, 35, England)

After that I went back to Ayers Rock [Uluru],
'cause I had a flight to Ayers Rock [Uluru], it
was part of my ticket. From there I got a bus to
Alice Springs, stayed there a couple of days and
got a truck to Darwin. (Sally, 24 , Holland)

The one thing I wanted to see was the Great Barnier Reef. To dive it, which I've done, and really enjoyed. (Cathy, 26, Scotland)

It is apparent that Veblen's form of emulation, in a touristic sense, is part of the stimulus for travel. Copying of others' travel plans, chartered routes, and ultimate destinations belies the very independence that these backpackers seek in touring the globe. Copying of others appears to build on their own symbolic standing and to give higher, bigger, and better goals to try to attain. This is a part of the contradiction between conformity and independence practiced by the backpacker subculture. According to Waller and Robertson (1998)

The politics of celebrity is the lynch pin of the consumer economy. The manufacture of enviable identities promotes the desire for emulation. The fundamental requirement is that one must be seen 
by others as possessed of the appropriate status signs and symbols in order to have social value or efficacy. The ideal definition of the participant in the consumer economy is one that entails selfcommodification, or the hollow triumph of becoming the figment of other people's imaginations. (p. 37)

In this instance, what Veblen asks us to question is how, in the absence of established social institutions and practices, the cultural bases of conspicuous consumption and invidious contrast are supported and perpetuated (Waller \& Robertson 1998 , p. 29).

Backpackers appear to adhere to a support system of their own by sticking together or by making new friends and keeping established friendships along the road (see Sorensen, 2003; Vogt, 1976). They are all very friendly towards each other and appear to look out for one another, especially if they are from the same country. This brings about a kind of solidarity and makes for group cohesion, particularly when they travel together for even a short period of time.

I've met some people and I'd travel with them for, oh, for probably about a week, a week or two, but Y've never met anybody l've traveled with longer. Everybody seems like really different [sic], you know itineraries. There's so much to do in Australia. So many different ways to go and find ... to work and things. So, not many people, not longer than two weeks. (Lee-anne, 26, Canada)

This backpacker further expands on this theme and explains why she backpacks, just like many others, and where she travels to, just like many others.

I guess ... for fun ... to get some independence perhaps. I guess, I think people want to expand their horizons ... to see how other parts of the world live (Lee-anne, 26, Canada)

Another female explains her travel behavior, which once again, is the imitation or emulation of others' backpacking journeys.

I've been to Sweden, Norway. I go skiing in Norway and Germany. I was skiing in Austria last Christmas. I've been to Italy. I went grape pick- ing in Tuscany. It's beautiful. I was also in London many years ago. I've made some friends now. A girl from Italy and one from Switzerland so, I'm going to visit them when I get back. l've been to Spain too, on the east coast for a holiday and I went to Barcelona too. I did a tour of the outback... Undara Lava Tubes. I went to Green Island, Fitzroy Island, I went to Cape Tribulation. Kuranda. (Evelyn, 24, Denmark)

Veblen (1934) theorizes that the emulation of others places individuals, and in this case backpackers, in an enviable position, they have gained the freedom to travel at will. In this study the backpackers portrayed themselves as freedom loving individuals who travel at their own discretion with no set itineraries. They form social networks, or "support groups," usually with others from their country of origin. The issues discussed in this section relate to an overall and broad perspective of some of the idiosyncrasies of backpackers as a group. Many of the backpackers appear to be almost clones of the others. Emulation of one another through bravado, travel destinations, "tall" stories and other trappings of nomadic behavior raises the notion of collective individualism (Mukerji, 1978; Noy, 2004).

Corrigan (1997) supports this line of thought and quotes Veblen (1899), remarking that, "conspicuous abstention from labour... becomes the conventional mark of superior pecuniary achievement and the conventional index of reputability" (p. 41). However, Veblen's (1899) argument has a tendency to assume that all classes want to emulate one another, instead of living as individuals (Corrigan, 1997, p. 26). In this study, it has been found that there is no individualism as the backpackers are a homogenous group. They all act and do similar things. They may believe that they are free from the emulation process, but the findings from the research belie this position.

\section{Status-Seeking or "Honorific" Behavior}

The notion of journeying, as a rite of passage, can be viewed as a validation and elevation of oneself. It can be used as an indicator of the position or status one has attained in life and that will be used in the years to come to construct one's identity as a pioneer and survivor. Likewise, levels of competency in other areas can also be a hall- 
mark of one's validity and worth in society. According to Veblen (1934), "leisure is honourable and becomes imperative partly because it shows exemption from ignoble labour" (p. 92).

One of the research participants suggests that backpacking is a unique form of travel that gives freedom to those who undertake it and brings a certain "elevated" status to those who travel in this manner.

Well, I have a big aversion to a tourist package at the best of times. The fact that I'm traveling with an Australian woman as well, obviously that gives me more of an insight into the places than other travelers would've had. There just wouldn't be a package for what we've just spent the last three months doing. No money would pay, could pay, anyone to do what we've done. (Julia, 28, Ireland)

As another form of elevated status connected to traveling, one backpacker explains how she experiences her preferred form of recreational activity.

Well ... I mean, it's fantastic, but umm... I think, the first time I dived was in Sydney, in the city. I mean, it was just in Manly and it's a suburb of Sydney and you think that there can't be anything there. If just blew my mind. You know, just there, near the buildings and modern living, there's all this life going on. (Regina, 35, England)

Other backpackers used the opportunity to celebrate themselves. One of the research participants used her travels in Australia to observe her birthday, and to use her time doing something she thought to be extraordinary. It seemed she needed individuals from her own country to validate and to mark her participation at an international competition.

I spent my birthday there. I just passed through Adelaide because I had these Canadian friends to meet in Perth, so I went to Perth. Spent two weeks in the city just going out with these friends. I thought about finding some job, but then $I$ didn't. So, I went to this surf contest in Margaret River, for a week, because I hadn't met any Brazilians yet. So I just, I knew that there would be some Brazilians there, and one or two Portuguese. So, I went all the way to Margaret River for a week. (Caterina, 25, Brazil)

Indeed, Veblen (1934) has a relevant explanation for this model of behavior.
So much of the honorable life of leisure as is not spent in the sight of spectators can serve the purposes of reputability only in so far as it leaves a tangible, visible result that can be put in evidence and can be measured and compared with products of the same class exhibited by competing aspirants for repute. (p. 49)

This, once again, is part of the contradiction of backpacker subculture, where even though independence is a key goal of the backpacker travel ethic, conformity of behavior is often the norm. Some of the backpackers saw their decision to travel to Australia and further, to travel alone, as a mark of their self-worth and independence.

For me, it is not a problem. Since I travel, it's like people are so, "Oh, you travel by your own [sic]. Oh, it's crazy." I put up with that because $\ldots$ and sometimes when people are around I say that I am engaged, that I am married. (Beris, 28, Tunisia)

Another traveler saw her experience as completely unstructured and unplanned. Her idea of travel had previously been as a couple, and structured travel. She saw her antipodean backpacking experience as a "bargain," value for money and completely wrong for someone from Europe. She will definitely boast about the bargains to be had in Australian tourism when she returns home.

I mean, this is completely on your own, minus your parents, minus say your boyfriend, your partner, where you'd probably get an all inclusive, this is like just taking us for half price. Which is kind of weird for us from London, because in London it's this, this, this, and this. In London everything is planned. (Jocelyn, 19, England)

Articulating the bargains to be experienced by backpackers from other countries while in Australia, and boasting that any single person (in this case, notably female person) can obtain for half price a fully comprehensive travel experience is perceived as a mark of status and secretly revered by others of the backpacking cohort (see Sorensen, 2003). Veblen (1934) expands on this interesting facet of backpacking bravado.

At a later stage of the development it is customary to assume some badge or insignia of honour 
that will serve as a conventionally accepted mark of exploit, and which at the same time indicates the quantity or degree of exploit of which it is the symbol. (p. 44)

All of the backpackers interviewed in this research see what they are doing as a unique and exclusive form of travel, where they can experience select forms of travel experience through the elevated status of the types of events they encounter. Status seeking through the perceived unique activities and alleged singular occurrences the backpackers relate, gives them, in their opinion, a "badge of honor" and an enhanced status level, where they can recount their stories through the use of enhanced storytelling and the use of bravado (Campbell, 1995, p. 42; Mukerji, 1978; Sorensen, 2003). They appear to believe that no other backpacker before them has had a particular or similar experience, and that they are the only ones to have experienced their unique time and activities in a manner unique to themselves. Thus, it follows that status-seeking behavior and bravado are mechanisms employed by long-term budget travelers and backpackers to justify their time away from home, the money they have outlaid, and the fact that their journey was unique and not experienced before by other individuals (Elsrud, 2001; Mukerji, 1978; Peel \& Steen, 2007, p. 1059; Sorensen, 2003).

As Veblen (1934) succinctly notes, "since the consumption of these more excellent goods is an evidence of wealth, it becomes honorific; and conversely, the failure to consume in due quantity becomes a mark of inferiority and demerit" (p. 74).

\section{Conclusion}

This article has shown that Veblen's (1899) notions of conspicuous consumption, conspicuous leisure, emulation, and status-seeking or honorific behavior can be applied to the class of independent traveler commonly referred to as backpackers, even though this group has not usually been perceived as being a part of the mainstream leisure or tourist classes. Thus, Veblen's thesis can be perceived as still relevant at the beginning of the 21 st century.

Contemporary independent tourists and budget travelers use Veblen's notions of conspicuous con- sumption, conspicuous leisure, emulation, and status-seeking or honorific behavior to elevate themselves and their experience in the global tourist market and amongst their peers (see Campbell, 1995, p. 45; Noy, 2004, 2008). The backpackers in this research show how they use fiscal exchange to their advantage. They wear their frugalness as a badge of honor and earn status points from other nomadic travelers for their perseverance and determination at adhering to the "unspoken" code of backpacker lore.

In some ways, the notion that backpackers seek to eschew the mainstream tourist market is misleading and contradictory. Many of these independent travelers use the mainstream tourist economy to exploit mainstream tourist operators if they know they can receive cheaper prices for tours, accommodation, food, and the "backpacker experience" than they could attain from and through backpacker networks. In other words, they seek out the cheapest "deal" for experiences, even if it means contravening the backpacker tradition of independence and self-sufficiency. The mantra here then is, cheap is good, no matter how you acquire it!

Veblen's original contention about the theory of the leisure class still has relevance in the $21 \mathrm{st}$ century global economy. This is significant because there appears to be no lull in the numbers of backpackers (or other travelers) roaming the planet in the search of the ultimate act of conspicuous consumption or conspicuous leisure. Veblen's theories of "conspicuous consumption" and "conspicuous leisure" link well to contemporary practices of 21 st century consumption. Clearly then, Veblen's work is as relevant today as it was when it was first written over 100 years ago. This is because it gives us a foundation for the understanding of the ideas implicit in backpacker travel, lore, emulation of one another, and other identifying features of these long-term budget travelers. The need of this subculture to consume conspicuously or otherwise can be more than adequately explained using Veblen's (1899) The Theory of the Leisure Class.

\section{Acknowledgments}

The author wishes to thank Editor-in-Chief, Wesley Roehl, and the two anonymous reviewers 
of Tourism Review International for their constructive and supportive comments on the initial submission of this article.

\section{Biographical Note}

Wendy Hillman has a Ph.D. in sociology, and is currently a Lecturer and researcher in sociology at CQUniversity in Queensland, Australia, where she is also a member of the Institute for Health and Social Science Research. She previously held the position of Postdoctoral Research Fellow in the School of Social Work and Applied Human Sciences at the St Lucia campus of the University of Queensland, Australia. She has researched and published in the areas of tourism, mobility, teaching sociology, fanily, sociological theory, social policy, and qualitative research methodologies. She continues to work in the research area of mobilities.

\section{References}

Anheier, H., Gerhards, J., \& Romo, F. (1995). Forms of capital and social structure in cultural fields: Examining Bourdieu's social topography. The American Journal of Sociology, 100(4), 859-903.

Appadurai, A. (1990). Disjuncture and difference in the global cultural economy. In M. Featherstone (Ed.), Global culture: Nationalism, globalisation and modernity (pp. 295-310). London: Sage.

Barrett, F. (1989). The independent guide to real holidays abroad. London: The Independent.

Bourdieu, P. (1984). Distinction: A social critique of the judgement of taste. Cambridge, MA: Harvard University Press.

Bourdieu, P. (1993). The field of cultural production: Essays on art and literature. Cambridge: Polity Press.

Brown, D. (1998a). Introduction. In D. Brown (Ed.), Thorstein Veblen in the twenty-first century: A commemoration of the theory of the leisure class (1988-1999) (pp. xii-xix). Cheltenham, UK: Edward Elgar.

Brown, D. (1998b). Be all you can be: Invidious self-development and its social imperative. In D. Brown (Ed.), Thorstein Veblen in the twenty-first century: A com. memoration of the theory of the leisure class (19881999) (pp. 49-69). Cheltenham, UK: Edward Elgar.

Buchanan, I., \& Rossetto, A. (1997). With my swag upon my shoulder: A comprehensive study of international backpackers to Australia (Occasional Paper No. 24). Canberra, Australia: Bureau of Tourism Research.

Campbell, C. (1995). Conspicuous confusion? A critique of Veblen's theory of conspicuous consumption. Sociological Theory, 13(1), 37-47.

Clifford, J. (1997). Routes: Travel and translation in the late twentieth century. Cambridge, MA: Harvard University Press.

Cohen, E. (1973). Nomads from affluence: Notes on the phenomenon of drifter-tourism. International Journal of Comparative Sociology, 14(1-2), 89-103.
Cohen, E. (1979a). A phenomenology of tourist experiences. Sociology, 13, 179-201.

Cohen, E. (1979b). Rethinking the sociology of tourism. Annals of Tourism Research, 6(1), 18-35.

Cohen, E. (1979c). The impact of tourism on the hill tribes of Northern Thailand. Internationales Asienforum, 10(1-2), 5-38.

Cohen, E, (1989). 'Primitive and remote' hill tribe trekking in Thailand. Annals of Tourism Research, 16(1), 30-61.

Coleman, R. (1983). The continuing significance of social class to marketing. Journal of Consumer Research, 10, $265-280$.

Corrigan, P. (1997). The sociology of consumption: An introduction. London: Sage Publications.

D'Andrea, A. (2006). Neo-nomadism: A theory of postidentitarian mobility in the global age. Mobilities, $l(1)$, $95-119$

Denzin, N., \& Lincoln, Y. (Eds.) (1994). Handbook of qualitative research. Thousand Oaks, CA: Sage.

Dewar, K. (2000). An incomplete history of interpretation from the big bang. International Journal of Heritage Studies, 6(2), 175-180.

Elsrud, T. (2001). Risk creation in travelling: Backpacker adventure narration. Annals of Tourism Research, 28(3), $597-617$.

Errington, F., \& Gerwertz, D. (1989). Tourism and anthropology in a postmodern world. Oceania, 60, 37-54.

Featherstone, M. (1991). Consumer culture and postmodernism. London: Sage.

Frow, J. (1997). Time and commodity culture: Essays in cultural theory and postmodernity. Oxford: Clarendon Press.

Gluckman, M. (1962). Les rites de passage. In M. Gluckman (Ed.), Essays on the ritual of social relations (pp. 1-52). Manchester: Manchester University Press.

Haigh, R. (1995). Backpackers in Australia (Occasional paper No. 20). Canberra, Australia: Bureau of Tourism Research.

Haight, A. (1997). Padded prowess: A Veblenian interpretation of the long hours of salaried workers. Journal of Economic Issues, 31, 29-38.

Hall, D., \& Kinnaird, V. (1994). A note on women travellers. In V. Kinnaird \& D. Hall (Eds.), Tourism: A gender analysis (pp. 188-209). Chichester: John Wiley and Sons.

Hillman, W. (1999). Searching for authenticity in touristic experience: Female backpackers in North Queensland. Unpublished Master of Social Science thesis, James Cook University, Townsville, Australia.

Jarvis, J. (1994). The billion dollar backpackers: The ultimate fully independent tourists. Melbourne: National Centre for Australian Studies, Monash University. Retrieved from http://www.arts.monash.edu.au/ncas/tour ism/Backpackers.htm

Johnson, R. (1993). Editor's introduction: Pierre Bourdieu on art, literature and culture. In R. Johnson (Ed.), The field of cultural production: Essays on art, and literature (pp. 1-28). Cambridge: Polity Press. 
Keltehear, A. (1993). The unobtrusive researcher: A guide to methods. St. Leonards: Allen and Unwin.

Lanfant, M.-F., Allcock, J., \& Bruner, E. (Eds.) (1995). International tourism: Identity and change. London: Sage.

Lash, S. (1991). Sociology of postmodernism. London: Routledge.

Lee, S. (1999). Private uses in public spaces. New Media and Society, I(3), 331 -350.

Loker, L. (1993). The backpacker phenomenon II: More answers to further questions. Townsville, Australia: James Cook University of North Queensland.

Loker-Murphy, L., \& Pearce, P. (1995). Young budget travelers: Backpackers in Australia. Annals of Tourism Research, 22(4), 819-843.

Lury, C. (1996). Consumer culture. New Brunswick, NJ: Rutgers University Press.

MacCannell, D. (1973). Staged authenticity: Arrangements of social space in tourist settings. American Journal of Sociology, 79(3), 589-603.

MacCannell, D. (1976). The tourist: A new theory of the leisure class. New York: Schocken Books Inc.

McFarland, F. (1991). Economic philosophy and American problems: Classical mechanism, Marxist dialectic, and cultural evolution. Savage, MD: Rowland and Littlefield Publishers Inc.

Mason, R. (1981). Conspicuous consumption: A study of exceptional consumer behaviour. New York: St Martin's Press.

Mason, R. (1998). The economics of conspicuous consumption: Theory and thought since 1700. Cheltenham, UK: Edward Elgar.

Meethan, K. (2001). Tourism in global society: Place, culture, consumption. Hampshire: Palgrave.

Miles, M., \& Huberman, A. (1994). Qualitative data analysis: An expanded source book. Thousand Oaks, CA: Sage.

Mukerji, C. (1978). Bullshitting: Road lore among hitchhikers. Social Problems, 25(3), 241-252.

Munt, I. (1994). The 'other' postmodern tourism: Culture, travel and the new middle classes. Theory, Culture and Society, 11(3), 101-123.

Murphy, L. (1998). Kangaroos, koalas and vegemite: Backpackers' images of Australia as a holiday destination. In Bureau of Tourism Research, Progress in tourism and hospitality research 1998, part 1. Proceedings of the eighth Australian tourism and hospitality research conference, February 11-14, 1987. Gold Coast, Australia: Bureau of Tourism Research.

Nash, D. (1989). Tourism as a form of imperialism. In V. Smith (Ed.), Hosts and guests: The anthropology of tourism (pp. 37-54). Philadelphia: University of Philadelphia Press.

Noy, C. (2004). This trip really changed me: Backpackers' narratives of self-change. Annals of Tourism Research, $31(1), 78-102$.

Noy, C. (2008). Traversing hegemony: Gender, body and identity in the narratives of Israeli female backpackers. Tourism Review International, 12(1), 1-22.

O'Reilly, C. (2006). From drifter to gap year tourist: Mainstreaming backpacker travel. Annals of Tourism Research, 33(4), 998-1017.

Pearce, P. (1990). The backpacker phenomenon: Preliminary answers to basic questions. Townsville, Australia: James Cook University of North Queensland.

Peel, V., \& Steen, A. (2007). Victims, booligans and cashcows: Media representations of the international backpacker in Australia. Tourism Management, 28, 10571067.

Ramstad, Y. (1998). Veblen's propensity for emulation: Is it passé? In D. Brown (Ed.), Thorstein Veblen in the twenty-first century: A commemoration of The Theory of the Leisure Class (1988-1999) (pp. 3-27). Cheltenham, UK: Edward Elgar.

Riley, P. (1988). Road culture of international long-term budget travelers. Annals of Tourism Research, 15(3), $313-328$.

Rojek, C. (1995). Veblen, leisure and human need. Leisure Studies, 14, 73-86.

Ross, G. (1992.) Backpacker visitors to the wet tropics region of far north Queensland, Technical report No. 2 . Department of Psychology and Sociology, Cairns Campus, Australia: James Cook University of North Queensland.

Ross, G. (1993). Ideal and actual images of backpacker visitors to northern Australia. Journal of Travel Research, 32(3), 54-57.

Sharpley, R. (1994). Tourism, tourists and society. Huntingdon, UK: ELM Publications.

Simpson, K. (2005). Dropping out or signing up? The professionalisation of youth travel. Antipode, 37(3), 447469.

Sorensen, A. (2003). Backpacker ethnography. Annals of Tourism Research, 30(4), 847-867.

Uriely, N., Yonay, Y., \& Simchai, D. (2002). Backpacking experiences: A type and form analysis. Annals of Tourism Research, 29(2), 520-538.

Urry, J. (1990). The tourist gaze: Leisure and travel in contemporary societies. London: Sage Publications.

Veblen, T. (1899). The theory of the leisure class: An economic study of institutions. New York: B. W. Huebsch.

Veblen, T. (1934). The theory of the leisure class: An economic study of institutions. Toronto, Canada: The Modern Library.

Vogt, J. (1976). Wandering: Youth travel and behavior. Annals of Tourism Research, 4(1), 25-41.

Waller, W., \& Robertson, L. (1998.) The politics of consumption and desire. In D. Brown (Ed.), Thorstein Veblen in the twenty-first century: A commemoration of the theory of the leisure class (1988-1999) (pp. 28-48). Cheltenham, UK: Edward Elgar.

Walmsley, D. (2003). Rural tourism: A case of lifestyle-led opportunities. Australian Geographer, 34(1), 61-72. 